\title{
ANALISIS PENGARUH FAKTOR EKSTERNAL TERUKUR TERHADAP DURASI PROYEK KONSTRUKSI DENGAN METODE PLS-SEM
}

\author{
Kelvin Ngunadi ${ }^{1}$ dan Basuki Anondho² \\ ${ }^{1}$ Program Studi Sarjana Teknik Sipil, Universitas Tarumanagara, Jl. Letjen S. Parman No.1 Jakarta \\ get_kelvin@hotmail.com \\ ${ }^{2}$ Program Studi Sarjana Teknik Sipil, Universitas Tarumanagara, Jl. Letjen S. Parman No.1 Jakarta \\ basukia@ft.untar.ac.id
}

\begin{abstract}
ABSTRAK
Pada jaman modern ini, pembangunan sangat memiliki peran penting khususnya untuk negara khususnya negara berkembang. Waktu, biaya dan kualitas merupakan tiga parameter yang paling signifikan dalam menentukan keberhasilan penuh pada suatu proyek konstruksi. Banyak faktor yang menyebabkan kerugian pada bidang konstruksi, khususnya faktor keterlambatan atau durasi proyek. Terdapat beberapa faktor penyebab terjadinya keterlambatan pada proyek konstruksi. Faktor ekternal menjadi salah satu pengaruh dalam durasi proyek konstruksi. Pada penelitian ini memperlihatkan pengaruh faktor eksternal apa saja yang mempengaruhi durasi proyek. Pengumpulan data telah didapat 53 data dari beberapa proyek yang sedang berjalan di sekitar Jakarta dan sekitarnya. Dalam penelitian ini PLS-SEM digunakan sebagai metode untuk menganalisa data. Faktor ekonomi, faktor sumber daya manusia, dan faktor teknologi menjadi varibel yang memiliki pengaruh dalam durasi proyek konstruksi. Namun luas lantai dan jumlah lantai juga berperan dalam menghitung durasi proyek.
\end{abstract}

Kata kunci: faktor eksternal, durasi proyek, PLS-SEM

\section{PENDAHULUAN}

\section{Latar Belakang}

Proyek konstruksi merupakan aktivitas ekonomi terbesar, khususnya di negara berkembang. Contohnya pada India, sektor konstruksi merupakan aktivitas ekonomi terbesar kedua setelah pertanian, dan telah berkontribusi sebesar $6 \%$ sampai 9\% Produk Domestik Bruto (PDB) di India selama 5 tahun belakangan ini dari pendaftaran pertumbuhan $8 \%$ - 10\% pertahunnya (Doloi et al., 2011)

Dalam semua proyek konstruksi, banyak faktor yang menyebabkan kerugian salah satunya adalah keterlambatan. Keterlambatan sendiri tidak jarang ditemui pada banyak proyek di berbagai lokasi. Beberapa faktor yang mempengaruhi melampaunya waktu, seperti kurangnya kinerja dari kontraktor, kesalahan desain, adanya perubahan perintah, pengambilan keputusan yang lama dari klien, kondisi tanah yang tidak terduga dan cuaca yang tidak menentu, akibatnya durasi konstruksi jadi sering sekali terabaikan (Jarkas, 2015).

Beberapa penelitian terdahulu yang melakukan penelitian mengenai hubungan antara konstruksi seperti kepuasan, ambiguitas peran, atau sikap, Structure Equation Modeling (SEM) cenderung menjadi metodologi pilihan (Monecke dan Leisch, 2012). Structure Equation Modeling (SEM) itu sendiri sebagai metode analisis multivariate, sebenarnya merupakan teknik hibrida yang meliputi aspek-aspek penegasan (confirmatory) dari analisis faktor, analisis jalur, dan regresi yang dapat dianggap sebagai kasus khusus dalam SEM (Sarwono, 2015).

Partial Least Square (metode kuadrat terkecil parsial) merupakan suatu prosedur alternatif dalam pengerjaan SEM yang biasanya mungkin banyak orang lebih mengenal SEM berbasis kovarian. Terdapat perbedaan yang cukup signifikan dalam penggunaan SEM dengan PLS dan SEM berbasis kovarian, dimana pada SEM berbasis kovarian memerlukan data yang harus terdistribusi secara normal oleh karena itu dalam pengujian normalitas data, sedangkan SEM dengan PLS tidak memerlukan normalitas data. Walapun begitu, data yang terdistribusi normal juga bisa digunakan dalam perhitungan SEM dengan PLS. SEM dengan PLS juga dapat menggunakan ukuran sampel yang kecil tidak seperti pada SEM berbasis kovarian yang mengharuskan penelitian menggunakan sampel yang besar (Sarwono,2015).

\section{Tujuan Penelitian}

Tujuan dari penelitian ini adalah memberikan penegasan atau (konfirmatory) dari penelitian mengenai faktor eksternal yang berkaitan dengan durasi proyek, serta mengetahui seberapa besar pengaruh faktor eksternal beserta dengan indikator-indikatornya dengan waktu penyelesaian proyek. 


\section{Waktu dan Durasi Proyek}

Waktu dan durasi memiliki perbedaan dalam pengartian, waktu menyatakan siang/malam, sedangkan durasi merupakan lama waktu yang dibutuhkan untuk menyelesaikan suatu kegiatan. Waktu proyek atau biasa disebut umur proyek adalah salah satu atribut penting dalam manajemen proyek. Kegagalan mengelola waktu proyek akan berakibat pada telatnya penyelesaian proyek. Penyelesaian proyek yang tidak tepat waktu dapat berakibat bengkaknya berbagai sumber daya proyek, terutama pada sumber daya manusia dan biaya pada proyek.

\section{Faktor Eksternal Yang Mempengaruhi Durasi Proyek}

Pada dasarnya faktor eksternal yang mempengaruhi proyek merupakan faktor-faktor berasal dari luar proyek dan biasanya tidak dapat diprediksi, seperti faktor ekonomi, faktor sumber daya, faktor cuaca, dan sebagainya. Pada dasarnya faktor eksternal yang disebut merupakan faktor variabel laten. Dalam beberapa penelitian terdahulu, seperti penelitian Assaf dan Al-Hejji (2005) tentang penyebab keterlambatan pada proyek konstruksi yang besar, faktor eksternal masuk menjadi salah satu penyebab keterlambatan proyek.

Chan et al.(2004) mengatakan bahwa faktor eksternal yang menpengaruhi durasi proyek dapat dterbagi menjadi 6 faktor utama, yaitu faktor ekonomi, faktor sosial, faktor politik, faktor fisik, faktor hubungan industri, dan faktor teknlogi. Faktor - faktor tersebut dalam PLS SEM dapat dikategorikan sebagai variable laten.

\section{SEM Berbasis PLS}

Persamaan struktural dengan metode partial least square (PLS-SEM) merupakan alternative estimasi model persamaan structural selain model berbasis kovarian (CB-SEM) yang selama ini telah dikenal dalam penelitian. PLS sendiri merupakan metode untuk membangun model prediktif yang memiliki banyak faktor dan sangat kolinear. Dimana model pengukuran digunakan untuk uji validitas dan reabilitas, sedangkan uji model structural digunakan untuk uji kausalitas (pengujuan hipotesis dengan model prediksi)

\section{METODOLOGI PENELITIAN}

\section{Studi Literatur}

Studi literatur yang dilakukan dalam penelitian ini adalah pencarian dan pengumpulan buku, jurnal, serta informasi lainnya mengenai faktor eksternal yang mempengaruhi durasi waktu pada proyek konstruksi. dalam melakukan penelitian ini juga menggunakan dua metode yaitu kualitatif dan kuantitatif, dimana studi literatur untuk menentukan faktor eksternal dan mempelajari pengertian mengenai PLS SEM merupakan metode kualitatif, dan pengumpulan kuesioner atau studi lapangan merupakan metode kuantitatif.

Menurut Neuman (2006), ada 4 tujuan dari studi literatur yaitu:

1. Menunjukan hubungan dengan kelompok ilmu dan memberikan kredibilitas.

2. Menunjukan jalur penelitian dan hubungan penelitian yang dilakukan sekarang.

3. Untuk mengintegrasikan dan merangkum perkembangan pada suatu area pengetahuan.

4. Untuk belajar dari pakar lainnya dan mendorong ide-ide baru

\section{Kuesioner}

Penelitian ini digunakan untuk mengecek hipotesis yang telah didapat pada studi literatur. Kuesioner dibentuk untuk menanyakan pendapat responden mengenai faktor eksternal yang mempengaruhi durasi proyek konstruksi. Skala yang digunakan pada penelitian ini adalah skala likert di mana terdapat 5 pilihan yang digunakan untuk melihat apakah responden setuju atau tidak terhadap pernyataan tersebut. Nomor satu menunjukan arti tidak setuju hingga ke nomor lima yaitu sangat setuju. Kuesioner ini juga memiliki sasaran khusus kepada responden yang bekerja dan berhubungan pada durasi proyek seperti Project Manager, Site Manager, Quality Surveyor dan diharapkan memiliki pendidikan minimal S1 dan pengalaman kerja minimal 5 tahun.

\section{Metode Analisis Data}

Penelitian ini menggunakan PLS-SEM yang dibantu dengan program SmartPLS 3.0 pada program komputer di mana data yang di dapat harus di masukan ke dalam Microsoft Excel dan di simpan dalam format .CSV (Comma Delimited).

\section{ANALISIS DAN PEMBAHASAN}

\section{Identifikasi Faktor Eksternal}

Identifikasi faktor eksternal telah diambil dari 11 jurnal dan telah dirangkum pada tabel 1. 
Tabel 1. Rangkuman Identifikasi Faktor Eksternal

\begin{tabular}{|l|l|}
\hline Faktor Eksternal & Indikator \\
\hline Faktor Ekonomi & Inflasi \\
\cline { 2 - 2 } & Material \\
\cline { 2 - 2 } & Nilai Tukar \\
\cline { 2 - 2 } & PDB \\
\cline { 2 - 2 } & Suku bunga \\
\hline Faktor Sumber Daya Manusia & Kesehatan \\
\cline { 2 - 2 } & Ketersediaan Tenaga Kerja \\
\cline { 2 - 2 } & Pendidikan \\
\cline { 2 - 2 } & Pengalaman Kerja \\
\hline Faktor Teknologi & Inovasi \\
\cline { 2 - 2 } & Ketersediaan \\
\cline { 2 - 2 } & Penyerapan \\
\hline Durasi & Luas lantai \\
\cline { 2 - 2 } & Jumlah lantai \\
\hline
\end{tabular}

\section{Distribusi dan Pengumpulan Data}

Penelitian ini telah melakukan distribusi kuesioner kepada 16 proyek di Jakarta dan sekitarnya. Sebanyak 70 kuesioner telah di bagikan dalam kurun waktu kurang lebih tiga bulan dan telah berhasil mengumpulkan data sebanyak 53 kuesioner yang telah balik dan masuk kriteria.

\section{Analisis Data PLS-SEM}

Proses untuk menganalisis data dilakukan dengan menggunakan software SmartPLS 3.0. Setelah penginputan data serta pembuatan konstruk pada program tersebut, lalu dilakukan perhitungan data, maka akan keluar hasil seperti pada gambar 1.

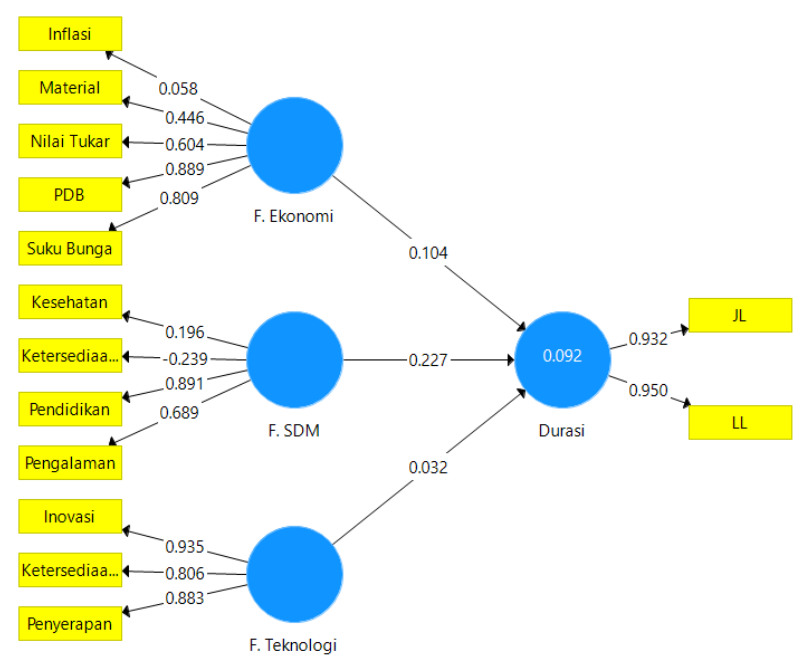

Gambar 1. Perhitungan Dengan SmartPLS 


\section{Outer Model}

Penilaian bagian luar (outer model) terdiri dari beberapa bagian, yaitu pengecekan pengecekan reliabilitas dan pengecekan validitas. Penilaian pertama dimulai dengan pengecekan nilai reliabilitas dan validitas dari penelitian lalu di lanjutkan dengan reliabilitas indikator. Namun untuk melihat apakah terdapat penghilangan atau pereduksian data dilakukan pengejekan outer loading yang dapat dilihat pada tabel 2.

Tabel 2. Outer Loadings

\begin{tabular}{|c|c|c|c|c|}
\hline \multicolumn{5}{|c|}{ Outer Loadings } \\
\hline & Durasi & Faktor Ekonomi & Faktor SDM & Faktor Teknologi \\
\hline Inflasi & & 0.058 & & \\
\hline Inovasi & & & & 0.935 \\
\hline $\mathrm{JL}$ & 0.932 & & & \\
\hline Kesehatan & & & 0.196 & \\
\hline Ketersediaan Tenaga Kerja & & & -0.239 & \\
\hline Ketersediaan Teknologi & & & & 0.806 \\
\hline LL & 0.950 & & & \\
\hline Material & & 0.446 & & \\
\hline Nilai Tukar & & 0.604 & & \\
\hline PDB & & 0.889 & & \\
\hline Pendidikan & & & 0.891 & \\
\hline Pengalaman & & & 0.689 & \\
\hline Penyerapan & & & & 0.883 \\
\hline Suku Bunga & & 0.809 & & \\
\hline
\end{tabular}

Outer Loadings (Muatan Luar) memiliki nilai minimal sebesar 0.5, karena setiap variabel laten dapat menjelaskan varian indikatornya masing-masing setidak-tidaknya sebesar 50\% (Sarwono dan Narimawati, 2015). Apabila nilainya kurang dari 0.4, maka indikator tersebut dihapuskan, oleh karena itu dapat disimpulkan bahwa:

- Pada Faktor Ekonomi memiliki indikator yang bernilai dibawah 0.4, yaitu inflasi, dan terdapat indikator yang terbilang kecil yaitu harga material dengan nilai 0.446, sedangkan 3 indikator lainnya memiliki nilai di atas 0.5 yaitu nilai tukar, PDB dan suku bunga. Oleh karena itu, indikator inflasi dihilangkan.

- Pada Faktor SDM terdapat 2 indikator yang memiliki nilai <0.4, yaitu kesehatan dan ketersediaan tenaga kerja, sedangkan 2 indikator lainnya memiliki nilai diatas 0.5 sehingga variabel kesehatan dan ketersediaan tenaga kerja dihilangkan.

- Semua indikator pada faktor teknologi memiliki nilai $>0.4$ yaitu inovasi, ketersediaan teknologi dan penyerapan teknologi.

- Semua Indikator pada variabel durasi memiliki nilai $>0.4$ yaitu indikator luas lantai dan jumlah lantai.

Dikarenakan adanya penghilangan beberapa variabel pada konstruk awal, maka dilakukan lagi perhitungan kedua dengan SmartPLS, hasil dari perhitungan ulang dapat dilihat pada gambar 2. 


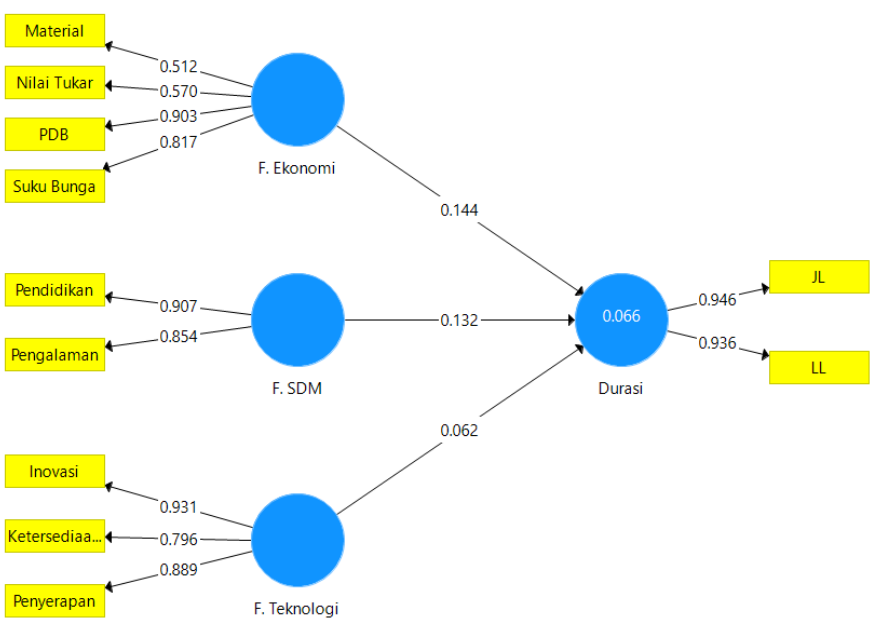

Gambar 2. Perhitungan Lanjutan dengan SmartPLS

Setelah dilakukan perhitungan ulang dengan pereduksian variabel yang tidak memenuhi syarat, didapatkan hasil seperti diatas. Kemudian dilanjutan dengan pengecekan reliabilitas dan validitas yang dapat dilihat pada tabel 3.

Tabel 3. Cronbach's Alpha dan Composite Reliability

\begin{tabular}{|l|r|r|}
\hline & Cronbach's Alpha & Composite Reliability \\
\hline Durasi & 0.872 & 0.940 \\
\hline Faktor Ekonomi & 0.702 & 0.803 \\
\hline Faktor SDM & 0.714 & 0.874 \\
\hline Faktor Teknologi & 0.867 & 0.906 \\
\hline
\end{tabular}

Dari tabel tersebut dapat disimpulkan bahwa:

- Variabel laten durasi sangat andal karena nilai Cronbach's Alpha berkisar antara 0.8 - 1.0 yaitu 0.872, dan memiliki nilai pengaruh konsistensi internal masuk kriteria yaitu diatas 0.6 yaitu 0.940 .

- Variabel laten faktor ekonomi dan faktor SDM memiliki nilai andal karena nilai Cronbach's Alpha berkisar antara 0.6 - 0.8 yaitu 0.702 dan 0.714 , dan memiliki nilai pengaruh konsistensi internal masuk kriteria yaitu diatas 0.6 yaitu 0.803 dan 0.874 .

- Variabel laten faktor teknologi memiliki nilai sangat andal karena nilai Cronbach's Alpha berkisar antara 0.8 1.0 yaitu 0.867 , dan memiliki nilai pengaruh konsistensi internal masuk kriteria yaitu diatas 0.6 yaitu 0.906.

Selain pengecekan nilai reliabilitas, perlu juga diperiksa validitas. Dalam penelitian ini, pengecekan nilai validitas dapat dilihat pada nilai AVE (Average Variance Extracted). Nilai AVE digunakan untuk pengecekan validitas konvergen yang menentukan apakah variabel laten mampu menjelaskan lebih setengah variabel indikatornya. Nilai AVE dapat dilihat pada tabel 4.

Tabel 4. Average Variance Extracted

\begin{tabular}{|l|r|r|r|r|}
\hline & Durasi & Faktor Ekonomi & Faktor SDM & \multicolumn{1}{|l|}{ Faktor Teknologi } \\
\hline AVE & 0.886 & 0.517 & 0.776 & 0.764 \\
\hline
\end{tabular}

Nilai AVE pada setiap variabel laten berada di atas 0.5 . Hal ini menunjukan validitas konvergen yang memadai dan mempunyai arti bahwa satu variabel laten mampu menjelaskan lebih dari setengah varian dari indikator-indikatornya dalam rata-rata. Setelah data telah diperiksa reliabilitas dan validitasnya, dilanjutkan dengan perhitungan muatan luar (outer loadings). Tabel perhitungan dapat dilihat pada tabel 5. 
Tabel 5. Outer Loadings

\begin{tabular}{|l|l|l|l|l|}
\hline & Durasi & Faktor Ekonomi & Faktor SDM & Faktor Teknologi \\
\hline Inovasi & & & & 0.931 \\
\hline JL & 0.946 & & & \\
\hline Ketersediaan 2 & & & & 0.796 \\
\hline LL & 0.936 & & & \\
\hline Harga Material & & 0.512 & & \\
\hline Nilai Tukar & & 0.570 & & \\
\hline PDB & & 0.903 & & \\
\hline Pendidikan & & & 0.907 & \\
\hline Pengalaman & & & 0.854 & \\
\hline Penyerapan & & & & 0.889 \\
\hline Suku Bunga & & 0.817 & & \\
\hline
\end{tabular}

Penilaian pada tabel diatas dapat disimpulkan bahwa:

- Pada faktor ekonomi indikator PDB dan suku bunga memiliki nilai diatas 0.7 yang berarti bahwa indikator tersebut dapat dijelaskan dalam variabel laten faktor ekonomi, sedangkan indikator nilai tukar memiliki nilai diantara $0.5-0.7$ yang berarti indikator tersebut cukup dijelaskan dalam variabel laten faktor ekonomi,

- Pada faktor SDM, indikator pendidikan dan pengalaman memiliki nilai lebih dari 0.7 yang berarti indikator tersebut dapat dijelaskan dalam variabel laten faktor ekonomi,

- Pada faktor teknologi, indikator inovasi, ketersediaan teknologi dan penyerapan teknologi memiliki nilai lebih dari 0.7 yang berarti indikator tersebut dapat dijelaskan dalam variabel laten faktor ekonomi,

- Dalam variabel laten durasi, indikator luas lantai dan jumlah lantai memiliki nilai lebih dari 0.7 dapat dijelaskan dalam variabel laten durasi.

Cross loadings digunakan untuk mengecek validitas diskriminan yang apabila nilai indikator memiliki korelasi lebih tinggi dengan variabel laten lainnya daripada variabel latennya sendiri maka kecocokan model harus di pertimbangkan (Sarwono dan Narimawati, 2015). Nilai Cross loadings dapat dilihat pada tabel 6.

Tabel 6. Cross Loadings

\begin{tabular}{|l|l|l|l|l|}
\hline & Durasi & Faktor Ekonomi & Faktor SDM & Faktor Teknologi \\
\hline Inovasi & 0.152 & 0.048 & 0.442 & $\mathbf{0 . 9 3 1}$ \\
\hline JL & $\mathbf{0 . 9 4 6}$ & 0.190 & 0.212 & 0.154 \\
\hline Ketersediaan 2 & 0.019 & 0.186 & 0.354 & $\mathbf{0 . 7 9 6}$ \\
\hline LL & $\mathbf{0 . 9 3 6}$ & 0.182 & 0.198 & 0.120 \\
\hline Harga Material & 0.043 & $\mathbf{0 . 5 1 2}$ & 0.124 & -0.028 \\
\hline Nilai Tukar & 0.058 & $\mathbf{0 . 5 7 0}$ & 0.146 & 0.144 \\
\hline PDB & 0.217 & $\mathbf{0 . 9 0 3}$ & 0.288 & 0.062 \\
\hline Pendidikan & 0.210 & 0.445 & $\mathbf{0 . 9 0 7}$ & 0.457 \\
\hline Pengalaman & 0.171 & 0.173 & $\mathbf{0 . 8 5 4}$ & 0.497 \\
\hline Penyerapan & 0.126 & 0.116 & 0.560 & $\mathbf{0 . 8 8 9}$ \\
\hline Suku Bunga & 0.144 & $\mathbf{0 . 8 1 7}$ & 0.407 & 0.100 \\
\hline
\end{tabular}

Dari tabel tersebut dapat disimpulkan bahwa nilai pada setiap variabel indikator berada pada variabel latennya, sehingga konstruk dari pemodelan PLS-SEM ini dapat digunakan.

Selain pengecekan validitas diskriminan dengan menggunakan cross loadings, pengecekan juga dilakukan menurut kriteria Fornell-Larcker yang mengharuskan nilai AVE setiap variabel laten harus lebih besar dari nilai $\mathrm{R}^{2}$ (Sarwono dan Narimawati, 2015). Perbandingan nilai tersebut dapat dilihat pada tabel 7. 
Tabel 7. Perbandingan AVE dan $\mathrm{R}^{2}$

\begin{tabular}{|c|c|c|c|c|}
\hline & Durasi & $\begin{array}{l}\text { Faktor } \\
\text { Ekonomi }\end{array}$ & Faktor SDM & $\begin{array}{l}\text { Faktor } \\
\text { Teknologi }\end{array}$ \\
\hline AVE & 0.886 & 0.517 & 0.776 & 0.764 \\
\hline $\mathrm{R}^{2}$ & 0.066 & & & \\
\hline
\end{tabular}

Dari tabel diatas dapat dilihat bahwa nilai AVE lebih besar daripada nilai $\mathrm{R}^{2}$ dan menunjukan bahwa kriteria FornellLarcker terpenuhi.

\section{Inner Model}

Penilaian bagian dalam (inner model) merupakan penilaian hubungan antara masing-masing variabel latennya. Penilaian ini dapat dilihat pada nilai $\mathrm{R}^{2}, \mathrm{f}^{2}$ dan korelasi variabel laten. Nilai $\mathrm{R}^{2}$ dapat dilihat pada tabel 8.

Tabel 8. $\mathrm{R}^{2}$

\begin{tabular}{|c|c|c|c|c|}
\hline & Durasi & $\begin{array}{l}\text { Faktor } \\
\text { Ekonomi }\end{array}$ & Faktor SDM & $\begin{array}{l}\text { Faktor } \\
\text { Teknologi }\end{array}$ \\
\hline $\mathrm{R}^{2}$ & 0.066 & & & \\
\hline
\end{tabular}

Nilai $\mathrm{R}^{2}$ pada penelitian ini adalah 0.066 yang menunjukan bahwa hubungan antar setiap masing-masing variabel laten berada dalam kategori lemah (Chin, 1988). Setelah melihat nilai $\mathrm{R}^{2}$ dilanjutkan dengan melihat nilai pengaruh $\mathrm{f}^{2}$ yang dapat dilihat pada tabel 4.9 .

Tabel 9. $\mathrm{f}^{2}$

\begin{tabular}{|l|l|l|l|l|}
\hline & Durasi & $\begin{array}{l}\text { Faktor } \\
\text { Ekonomi }\end{array}$ & Faktor SDM & $\begin{array}{l}\text { Faktor } \\
\text { Teknologi }\end{array}$ \\
\hline Durasi & & & & \\
\hline F. Ekonomi & 0.019 & & & \\
\hline F. SDM & 0.011 & & & \\
\hline F. Teknologi & 0.003 & & & \\
\hline
\end{tabular}

Nilai $\mathrm{f}^{2}$ pada penelitian ini berada pada kategori lemah, dimana menurut Sarwono dan Narimawati (2015) nilai 0.02 pada $\mathrm{f}^{2}$ dikategorikan sebagai pengaruh lemah variabel laten prediktor (variabel laten eksogenus) pada tataran struktural.

\section{KESIMPULAN}

Berdasarkan analisis data yang telah dilakukan, dapat disimpulkan beberapa hal, yaitu :

1. Tedapat beberapa indikator yang direduksi atau dihilangkan karena memiliki nilai loading yang berada dibawah 0,4 yaitu indikator inflasi, kesehatan dan ketersediaan tenaga kerja.

2. Faktor eksternal yang paling berpengaruh terhadap durasi proyek konstruksi adalah PDB pada faktor ekonomi dengan nilai loading 0.903, pendidikan pada faktor SDM dengan nilai loading 0.907 , dan inovasi pada faktor teknologi dengan nilai loading 0.931 .

\section{SARAN}

Dari penelitian yang telah dilakukan sesuai dengan tahapan - tahapan yang telah dijabarkan, penulis mempunyai beberapa saran untuk mengembangkan penelitian ini:

1. Menambahkan variabel indikator melalui proses studi literatur. Penambahan indikator menjadi lebih luas dan diharapkan mampu memberikan pengetahuan mengenai faktor eksternal yang mempengaruhi durasi proyek.

2. Dalam mengumpulkan data, diharapkan jumlah proyek lebih banyak, agar model yang dihasilkan dapat lebih merepresentasikan keadaan sebenarnya dan dapat lebih akurat.

3. Dalam mengumpulkan data, diharapkan batasan wilayah dapat melebihi Jakarta dan sekitarnya agar data dijadikan dokumen data. 


\section{DAFTAR PUSTAKA}

Abdillah, Willy dan Hartono, Jogianto. Partial Least Square (PLS) - Alternatif Structural Equation Modeling (SEM) dalam Penelitian Bisnis. Yogyakarta: Penerbit Andi, 2015.

Adeleke, A.Q., Bahaudin, A. Y., dan Kamaruddeen, A.M. (2016). Moderating Effect of Regulations on Organizational Factor and Construction Risk Management: A Proposed Framework. International Journal of Economics and Financial Issues, 2016, 6(S7) 92-97.

Akanni, P.O., Oke, A.E., dan Akpomiemie, O.A. (2014). Impact of environmental factors on building project performance in Delta State, Nigeria. Housing and Building National Research Center.

Alaghbari, Wa'el et al. (2007). The significant factors causing delay of building construction project in Malaysia. Engineering, Construction and Architectural Management, Vol. 14 Iss 2 pp. 192-206.

Anastasopoulos, Panagiotis Ch., et al. (2012). Empirical Assessment of the Likelihood and Duration of Highway Project Time Delays. Journal of Construction Engineering and Management, 138(3): 390-398.

Anondho, Basuki, Latief, Yusuf dan Makarim, Chaidir Anwar (2015). Model Development for Estimating Probabilistic Project Duration using Quantify External Factor Influence. The $14^{\text {th }}$ International Conference on QiR, 2015.

Assaf, Sadi A dan Al-Hejji, Sadiq. (2005). Causes of Delay in Large Construction Projects. International Journal of Project Management 25 (2006) 349-357.

Aziz, Remon Fayek (2013). Ranking of delay factors in construction projects after Egyptian revolution. Alexandria Engineering Journal (2013) 52, 387-406.

Bamgbade, J.A, Kamaruddeen, A.M., dan Nawi, M.N.M. (2015). Factors Influencing Sustainable Construction among Construction Firms in Malaysia: A Preliminary Study using PLS-SEM. University of Nairobi Vol. 38, No3, 132142.

Chan, Albert P.C., Scott, David dan Chan, Ada P.L. (2004). Factors Affecting the Success of a Construction Project. Journal of Construction Engineering and Management, 130(1): 153-155.

Doloi, Hemanta, et al. (2011). Analysing factors affecting delays in Indian construction projects. International Journal of Project Management, 30, 479-489.

Gebrehiwet, Tsegay dan Luo Hanbin (2017). Analysis of Delay Impact on Construction Project Based on RII and Correlation Coefficient: Empirical Study. Procedia Enginnering 196 (2017) 366-374.

Hussein, Ananda Sabil. (2015). Modul Ajar Penelitian Bisnis dan Manajemen Menggunakan Partial Least Square (PLS) dengan smartPLS 3.0.

Jarkas, Abdulaziz M. (2015). Predicting Contract Duration for Building Construction: Is Bromilow's Time-Cost Model a Panacea?. Journal of Construction Engineering and Management, 32(1): 05015004.

Kaming, Peter F., Utomo, F.X. Junaedi, dan Tanmargo, Agus S. (2007). Studi Mengenai Model Estimasi Durasi Konstruksi Bangunan Gedung. Konferensi Nasional Teknik Sipil I (KoNTekS I)- Universitas Atma Jaya Yogyakarta.

Love, Peter E. D., Tse, Raymond Y. C., dan Edwards, David J. (2005). Time-Cost Relationships ini Australian Building Construction Project. J.Constr. Eng. Manage., 2005, 131(2): 187-194.

Malhotra, Naresh K. (2012). Basic Marketing Research, $4^{\text {th }}$ Edition. Georgia Institute of Technology.

Marzouk, Mohamed M. dan El-Rasas, Tarek I. (2012). Analyzing delay causes in Egyptian construction projects. Journal of Advanced Research (2014) 5, 49-55.

McDaniel, Carl dan Gater, Roger (2013). Marketing Research. John Wiley \& Sons; International student edition edition.

Monecke, Armin dan Leisch, Friedrich. (2012). semPLS: Structural Equation Modeling Using Partial Least Squares.

Musa. Mohammed Mukhtar et al. (2015). Influence of External Environmental Factors on the Success of Public Housing Project in Developing Countries. Construction Economics and Building, 15(4), 30-44.

Naik, M. Gopal dan Kumar, D. Rupesh (2015). Construction Project Cost and Duration Optimization Using Artificial Neural Network. AEI 2015.

Odeh, Abdalla M. dan Battaineh, Hussin T. (2001). Causes of construction delay: traditiona contracts. Internationa Journal of Project Management 20 (2002) 67-73.

Sambasivan, Murali dan Soon, Yau Wen (2006). Causes and effects of delays in Malaysian construction industry. International Journal of Project Management 25, (2007) 517-526.

Sarwono, Jonathan dan Narimawati, Umi, Membuat Skripsi, Tesis dan Disertasi demgam Partial Least Square SEM (PLS - SEM). Yogyakarta: Penerbit Andi, 2015.

Sugiyono (2009). Metode Penelitian Kuantitatif, Kualitatif dan R\&D, Bandung : Alfabeta.

Wen, Qi, Qiang, Maoshan, dan An, Nan. (2017). Collaborating with Construction Management Consultants in Project Execution: Responsibility Delegation and Capability Integration. Jousnal of Construction Engineering and Management, 143(7): 04017021. 